\title{
The entrance as a complex ecotone in a Neotropical cave
}

\author{
Xavier Prous ${ }^{1}$, Rodrigo Lopes Ferreira ${ }^{1}$, and Claudia M. Jacobi ${ }^{2}$ \\ ${ }^{1}$ Centro de Estudos em Biologia Subterrânea, Setor de Zoologia, Departamento de Biologia, Universidade Federal de Lavras, \\ CEP 37200-000, Lavras, MG, Brazil \\ ${ }^{2}$ Laboratório de Interações Animal-Planta, Departamento de Biologia Geral, ICB, Universidade Federal de Minas Gerais, Brazil
}

\begin{abstract}
Cave entrances are transition zones with intermediate characteristics between epigean environments, which bear lower environmental stability, and hypogean environments, with lower food resources. Associated to these interfaces there is a specific community, capable of exploiting its unique and intermediate characteristics. This work investigated this community in a Brazilian limestone cave, identifying its arthropod species composition and spatial distribution, and exploring its relationships with climatic and structural environment characteristics and trophic relations. An ecotone zone was identified, with 55 species found only in the ecotone, 49 species were shared with the epigean community, 37 species with the hypogean community, and 14 species were found in the three communities. Although detritus is the base of the trophic web in the entrance, light allows the establishment of some producers and even herbivores. Species diversity in the ecotone was intermediate to that of the adjacent environments. Light is the main filter that acts near the cave entrance and determines the presence and distribution of several species in the ecotone. Therefore, this region is important for the cave ecosystem as a whole, considering that a considerable amount of trophic resources is transferred from the epigean to the hypogean environment through this area. Accordingly, conservation and management strategies regarding cave communities should incorporate actions to study and protect ecotonal communities.
\end{abstract}

Keywords: $\quad$ cave entrance; ecotone; community; arthropods; Neotropic

Received 7 April 2013; Revised 5 February 2015; Accepted 11 February 2015

Citation: $\quad$ Prous X., Lopes Ferreira R. and Jacobi C.M., 2015. The entrance as a complex ecotone in a Neotropical cave. International Journal of Speleology, 44 (2), 177-189. Tampa, FL (USA) ISSN 0392-6672 http://dx.doi.org/10.5038/1827-806X.44.2.7

\section{INTRODUCTION}

The typical cave environment is considered climatically stable, possessing constant temperatures (close to the external annual average), relative humidity close to saturation and permanent absence of light (Poulson \& White, 1969). Almost all the nutrients present in cave environments are imported from epigean environments, except for chemoautotrophic organisms and roots that grow from epigean plants (Howarth, 1983; Sarbu et al., 1996; Engel, 2005; Poulson, 2005; Souza -Silva et al., 2012). The import of organic matter from the external environment to the caves occurs via physical or biological agents (Culver, 1982; Howarth, 1983; Poulson, 2005). Rivers, runoff and percolation water can carry large amounts of organic matter in the form of leaves, tree fragments, animal carcasses and dissolved organic compounds (Gibert et al., 1997; Souza-Silva et al., 2012). Feces and carcasses of animals that enters in caves (accidentally or intentionally) are also important sources of resources, especially in caves where there is no water (Culver, 1982; Howarth,
1983; Ferreira \& Martins, 1998; \& Ferreira Martins, 1999; Poulson, 2005).

The cave entrance zones are subject to climatic variations in the external environment, undergoing daily and annual variations in temperature, humidity and light. Moreover, the direct or even reflected incidence of light allows the presence of photosynthetic organisms (Pentecost \& Zhaohui, 2001; Serena \& Meluzzi, 1997; Culver \& Pipan, 2009). The highest concentration of organic matter transported gravitationally (e.g., leaves, tree fragments) coupled to photosynthetic organisms makes the cave entrances areas with higher food resources when compared to the typical cave environment. These characteristics make the cave entrances transition regions between the epigean and hypogean environment and may be characterized as ecotones, where one can find elements of adjacent environments as well as exclusive elements (Prous et al., 2004; Culver, 2005).

Characteristics such as high diversity, influence the energy flow between adjacent environments and lack of knowledge about the effects of anthropogenic 
changes on these environments make ecotones important areas for the development of ecological studies (Risser, 1990; Risser, 1995; Fagan et al., 1999; Cadenasso et al., 2003; Fagan et al., 2003; Strayer et al., 2003; Prous et al., 2004). However, studies on terrestrial ecotones associated with cave entrances remain scarce (Culver \& Poulson, 1970; Prous et al., 2004; Hills et al., 2008; Novak et al., 2012).

The general objective of the present work was to study the composition and spatial distribution of an ecotone community located in the entrance of a cave in southeastern Brazil and the influence of the ecotone on the community structure. Here, we tested the hypothesis that there is an ecotone at the cave entrance, with biotic and abiotic characteristics shared with the adjacent environments.

\section{METHODOLOGY}

\section{Study area}

The study was conducted in the "Lapa do Mosquito" Cave (37'34"S, 44²4'45”W), a limestone cave located in Curvelo Municipallity, Minas Gerais state, southeastern Brazil. The cave has a horizontal projection of $1,357 \mathrm{~m}$ and five entrances, two in one extremity of the cave (including the main entrance), one skylight located in the median part of the cave and the last two entrances located in the opposite side of the cave conduit (Fig. 1). The main entrance (used in this study), is approximately $50 \mathrm{~m}$ wide and $20 \mathrm{~m}$ high. After a constriction by speleothems at $30 \mathrm{~m}$ from the entrance, the main cave conduit begins, with an average width of $20 \mathrm{~m}$. In the first $150 \mathrm{~m}$, this conduit has a floor covered with dried earth sediment, except for a few dripping points. After this stretch, the conduit connects to another crossed by a drainage that enters the cave through a topographically recessed opening located close to the main entrance (Fig. 1).

Trees and shrub vegetation are present at the entrance of the cave. Litter covers the soil in the outer area and the initial portion of the cave (approximately $10 \mathrm{~m})$. Bryophytes and algae are found on the walls and rock blocks on the ground until about $30 \mathrm{~m}$ from the entrance, where there is still a considerable presence of light.

\section{Methods}

The study was conducted in the rainy season, between January and April 2004. A network of $4 \mathrm{~m}^{2}$ grid cells was drawn on the ground throughout the area near the cave entrance, including the external environment. The grid cells stretched inside the cave to $68 \mathrm{~m}$ from the entry point where the luminosity reached a value of 0 Lux. Outside, five radii were layed out $20 \mathrm{~m}$ from the center point of the cave entrance where the grid cells transects were plotted.

Each of the cells received an identification number, 294 cells inside the cave and 124 in the outer area,
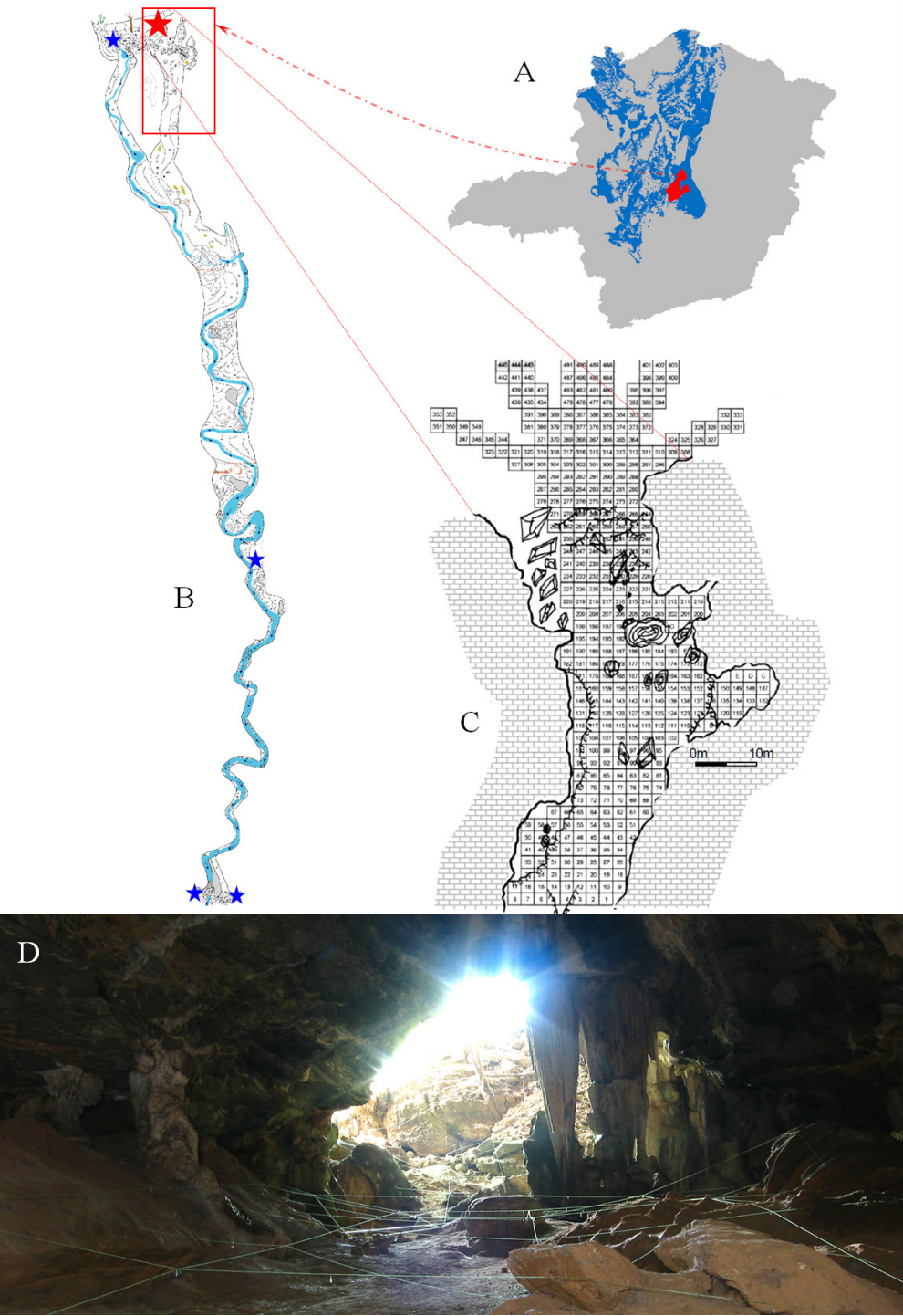

Fig. 1. Study area: A) Minas Gerais state (Brazil), with Bambuí limestone group (Blue) and Curvelo municipallity (red); B) Lapa do Mosquito cave. Blue stars indicated the entrances. The red star indicate the entrance used in this study;

C) Net of squares drawn under the study area. Each square has $2 \times 2$ meters;

D) The cave entrance with the net of squares.

totaling 418 grid cells. Within each cell the temperature and humidity were measured with the aid of thermohygrometer, the light with a light meter and the habitat structure evaluated. The measurements of temperature, humidity and luminosity were conducted in a single day, from 10:00 to $14: 00$ hours, to prevent huge variations on such conditions during the day. To assess habitat structure, each $4 \mathrm{~m}^{2}$ cell was divided into $100-400 \mathrm{~cm}^{2}$ plots. Each of these plots was classified according to the predominant substrate: stone, soil, rock, litter, tree fragments, guano, tree roots and speleothems. From the number of plots covered by each substrate, we calculated the structural diversity of the habitat from the Shannon index. The fall of a tree covered 37 grid cells in the external area during the execution of the work, preventing habitat structure measurements on this site.

From the estimate of the coverage percentage of each $4 \mathrm{~m}^{2}$ cell by each type of substrate, we also estimated the coverage percentage of each cell by organic matter, which is composed of guano, roots, litter, tree fragments and trees.

A thorough search for all arthropods present in each of the cells was conducted, and with the aid of tweezers 
and brushes those unidentified were collected on site. In this study, we made no distinctions between typically cave species and potentially accidental species, since we were focusing on the ecotone zone, which embraces species from both environments (epigean and hypogean). The few specimens belonging to well know genus occurring in Brazilian caves (e.g., Loxosceles, Endecous) were identified at the collection time and only few individuals were collected as evidence. All organisms collected were placed in vials containing $70 \%$ ethanol and identified with the number of each cell. In the outer area of the cave searches were aimed at environments with microclimatic characteristics similar to those of a cave environment, such as under rocks and tree fragments. In the laboratory, all organisms collected were identified to the lowest possible taxonomic level and separated into morphospecies.

Maps showing the distribution of the most frequent species and abiotic variables were made with the aid of the BoundarySeer version 1.2.0 (TerraSeer Inc. Software for Geographic Boundary Analysis, http://www.terraseer.com). In function of the very discrepant extreme values, luminosity values were converted to logarhythms.

\section{Analyses}

\section{Similarity matrix}

Using the methodology modified from Prous et al. (2004), we defined the distribution limits of the ecotone communities of the Lapa do Mosquito. The original method consists of comparing the species present in sectors equidistant from the cave entrance. In this study, each sector is made up of the area encluded by the grid cells of a same line at a specific distance from the entrance. That is, all grid cells equidistant in a straight line from the entrance are part of the same sector. It is assumed that the cave entrance is the ecotone centroid; thus, a reduction in the similarity values of correspondent sectors (in the epigean and hypogean zones) equidistant from the cave entrance would be expected as they are far from this centre. The limits of the ecotone are defined by the dissimilarity between the communities of the adjacent systems.

In the present work, two reference sectors were defined to trace the similarity between them and the other sectors. The two reference sectors are the most external, with the lowest possible hypogean environmental influences, and the sector located at the beginning of the cave (just below the dripline - entrance sector). To identify the presence of epigean organisms in the cave, we compared the similarity of fauna between the external reference sector with the other sectors. The second reference sector (the entrance sector) was used to determine the presence of ecotonal species in deeper areas of the cave (considering the sampled area). The similarity among the fauna present in the reference sectors and other sectors of the cave entrance, and the richness and diversity in each sector were used to delineate the ecotone community distribution.

To determine the similarity among sectors the qualitative Sørensen index (Magurran, 1988) was employed, since we sought only qualitative similarity, regardless of abundance. The matrix was made through the BioDiversity Pro program (The Scottish Association for Marine Science, http://www.sams. ac.uk/index.htm) and values were expressed as percentages of similarity.

\section{Relationship between environmental variables and species}

The richness and diversity were calculated for each sector defined as described in the similarity matrix. Diversity was calculated using the Shannon index. The relationships among different environmental variables, as well as the relationships between some of the most abundant species and environmental variables were analyzed by linear regression (Zar, 1996).

\section{RESULTS}

\section{Climatic variables and the physical environment}

The luminosity reached a 0 Lux value at $68 \mathrm{~m}$ from the entrance. A gradual increase from this point until the exterior was identified, where the edge of the cave had luminosity values very similar to those of external points (greater than 2000 Lux) (Fig. 2). The average temperature inside the cave $\left(19.8^{\circ} \mathrm{C}\right)$ was lower than outside $\left(26.6^{\circ} \mathrm{C}\right)$. A clear tendency for temperature homogeneity was observed in the portions more distant from the cave entrance (ranging from $18^{\circ}$ to $22^{\circ} \mathrm{C}$ ) while the external environment showed a wide temperature range, even between nearby grid cells (ranging from $21^{\circ}$ to $35^{\circ} \mathrm{C}$ ) (Fig. $3 \mathrm{~A}$ ). The humidity exhibited an inverse pattern to temperature, being higher inside the cave (average 63\%) and lower in the outer region (average 50\%), even considering that the sampling occurred in the reainy season. The area located between 20 and $40 \mathrm{~m}$ inside the cave had the highest relative humidity (average 73\%). In this

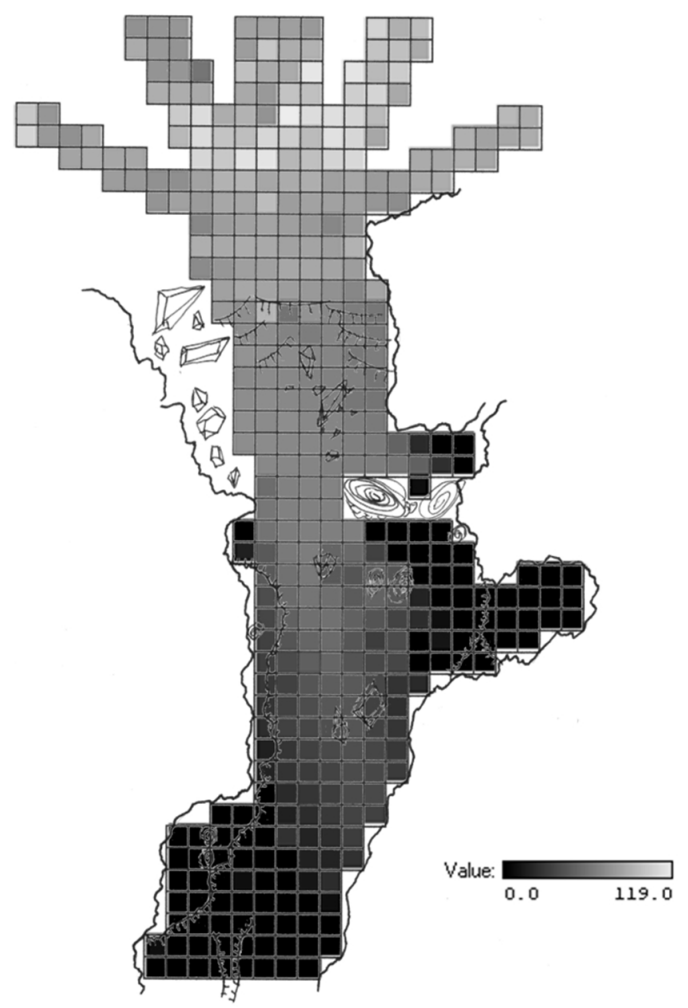

Fig. 2. Luminosity (In Lux * 10) in the studied grid cells. 
region, there were small puddles of water formed from percolating water dripping continuously (Fig. 3B).

The entire epigean environment and cave entrance had higher habitat diversity than the cave. Inside the cave, after $30 \mathrm{~m}$ away from the entrance, habitat diversity showed a decline, reaching the lowest

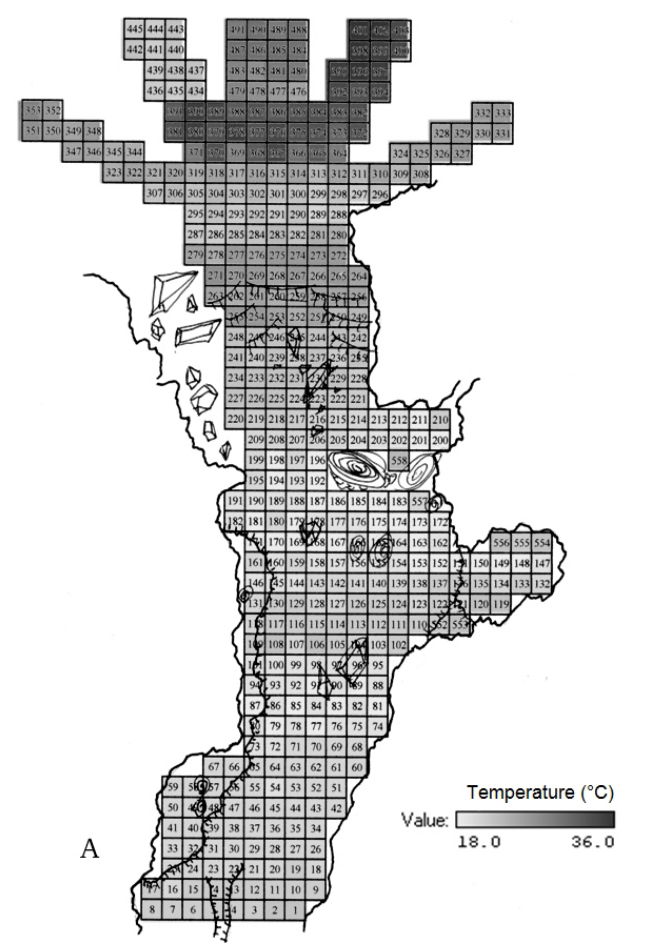

values starting from $40 \mathrm{~m}$ (Fig. 4A). The organic matter $(\mathrm{OM})$ found in the external cells was mainly composed of litter, some fallen tree trunks and a few tree fragments. All the external cells had part of their surface covered by OM, ranging from $30 \%$ to $98 \%$ coverage (Fig. 4B and Table 1).

Fig.3. Maps of $\mathrm{A}$ ) temperature $\left({ }^{\circ} \mathrm{C}\right)$ and $\mathrm{B}$ ) relative humidity (\%) studied in grid cells.
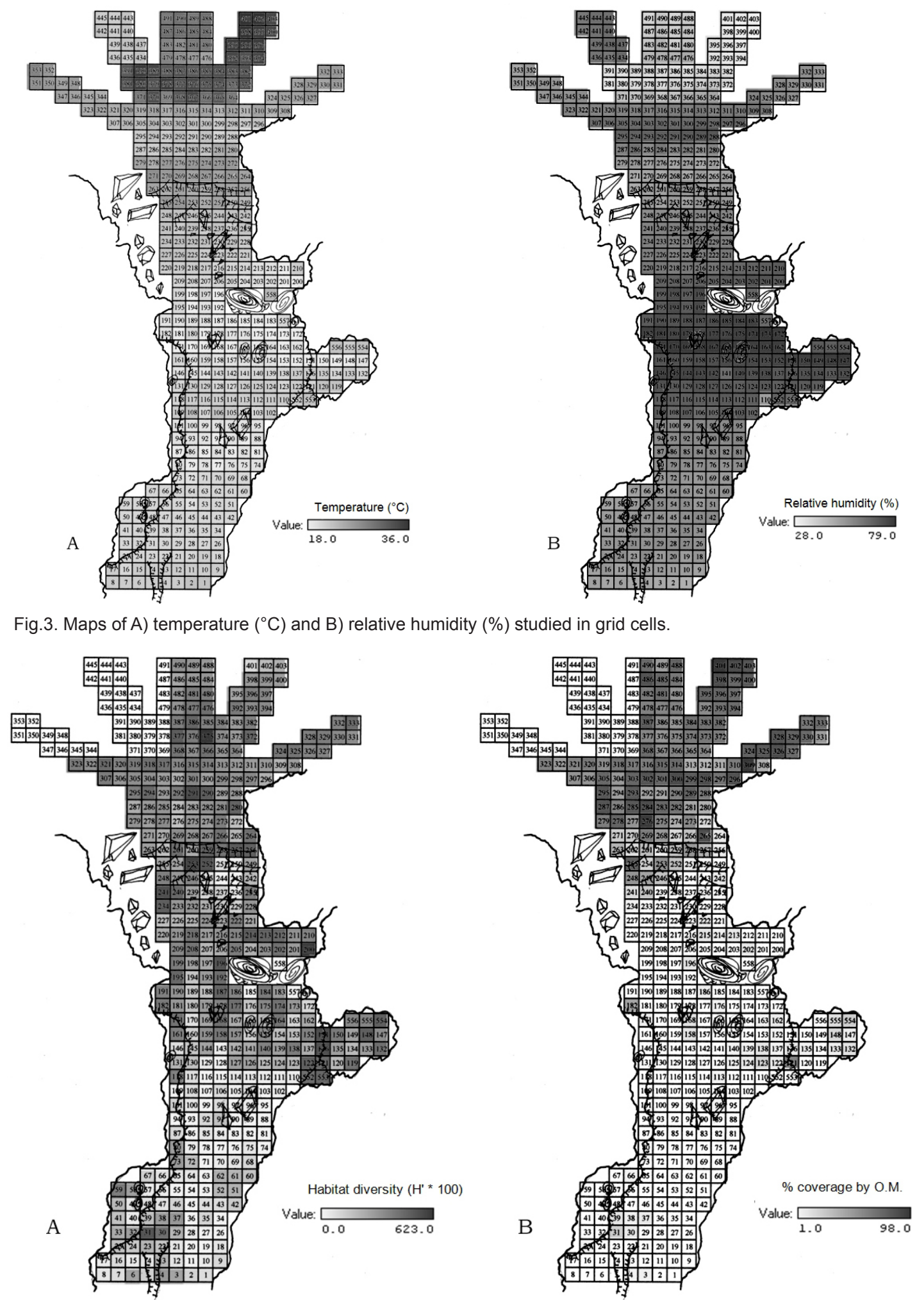

Fig. 4. Maps of A) habitat diversity $\left(\mathrm{H}^{\prime}\right)$ and $\mathrm{B}$ ) coverage of total organic matter - O.M. (guano, roots, litter and tree fragments).

Inside the cave, few patches of organic material were found. Two cells, located approximately $20 \mathrm{~m}$ from the entrance, stood out for having 40 and 58\% of their surface, respectively covered with bat guano. The other grid cells showed only a small percentage of their surface covered by O.M., generally roots or small tree fragments. In the first $10 \mathrm{~m}$ from the cave entrance a large number of cells were covered with litter brought by wind or gravity from the external environment. After $10 \mathrm{~m}$ from the entrance, 
Table 1. Average percentage of coverage of a grid for each type of structure and number of grid cells in each group (in bold the predominant substrate in each group).

\begin{tabular}{|c|c|c|c|c|c|c|c|c|c|c|}
\hline Group & $\mathbf{N}^{\circ}$. Grid cells & Tree & Speleothem & Litter & Guano & Stones & Roots & Rocks & Soil & Tree fragments \\
\hline 1 & 98 & 3.0 & 0.0 & $\mathbf{6 1 . 6}$ & 0.0 & 32.3 & 4.2 & 6.0 & 11.7 & \\
\hline 2 & 66 & 0.0 & 28.6 & 26.2 & 0.0 & $\mathbf{6 4 . 7}$ & 0.0 & 28.3 & 22.8 & 6.3 \\
\hline 3 & 184 & 0.0 & 12.6 & 40.0 & 8.3 & 12.0 & 5.6 & 15.0 & $\mathbf{8 4 . 4}$ & 2.6 \\
\hline 4 & 3 & 0.0 & 0.0 & 22.7 & 0.0 & 17.0 & 0.0 & $\mathbf{6 9 . 5}$ & 13.5 & 15.0 \\
\hline 5 & 2 & 0.0 & 46.0 & $\mathbf{6 3 . 0}$ & 0.0 & 14.0 & 0.0 & 0.0 & 0.0 & 0.0 \\
\hline 6 & 14 & 0.0 & 37.9 & 6.0 & 0.0 & 21.7 & 0.0 & 31.0 & $\mathbf{5 0 . 3}$ & 3.8 \\
\hline 7 & 13 & 0.0 & $\mathbf{6 4 . 3}$ & 3.0 & 5.0 & 14.8 & 0.0 & 0.0 & 33.5 & 1.0 \\
\hline 8 & 1 & 0.0 & 0.0 & 0.0 & 0.0 & $\mathbf{8 5 . 0}$ & 0.0 & 0.0 & 15.0 & 0.0 \\
\hline
\end{tabular}

food resources became scarce with only a few tree fragments, roots and quite old small guano deposits. Most of the organic matter present within the Lapa do Mosquito appears to be imported via a stream which penetrates through the cave or in the form of bat feces.

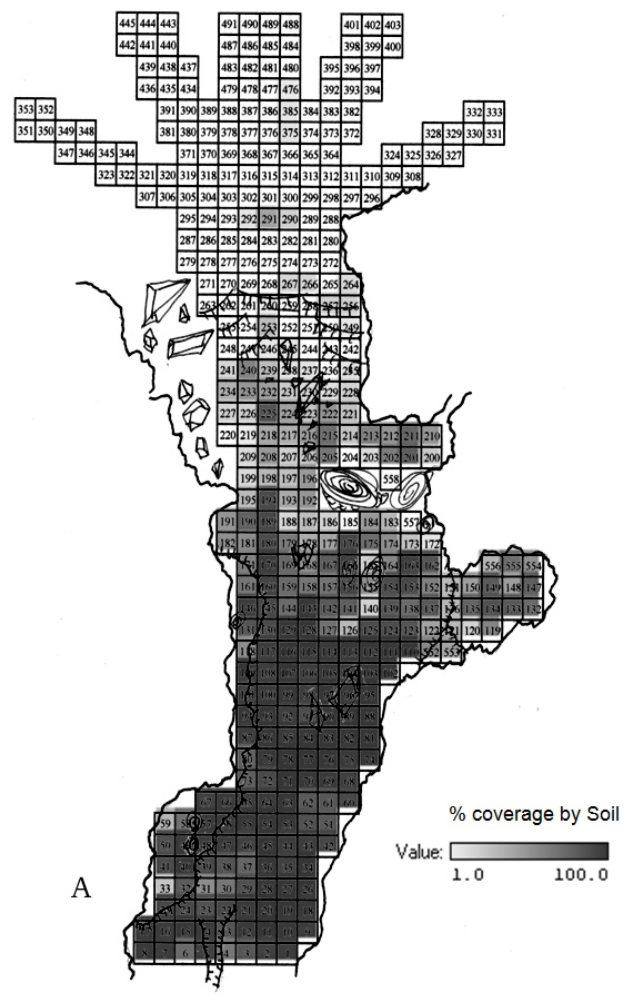

The predominant substrates on the cave floor were earth and stones. The cells located more than $30 \mathrm{~m}$ away from the entrance were almost entirely covered with earth (Fig. 5A), while those located near the entrance (from 0 to $30 \mathrm{~m}$ from the cave) had many stones covering the floor (Fig. 5B).

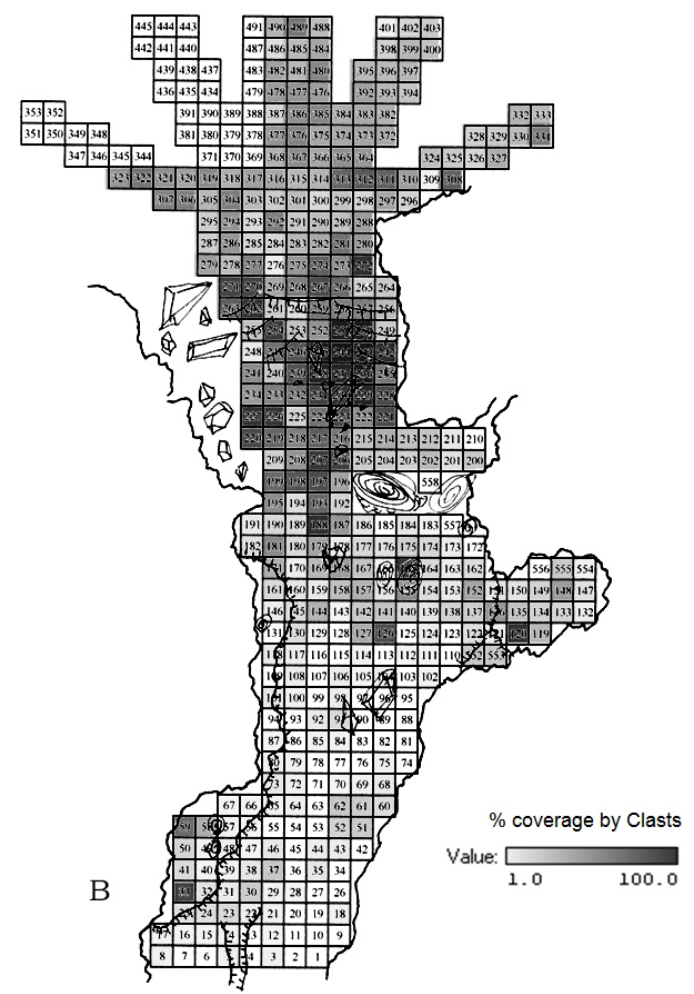

Fig. 5. Maps indicating the coverage percent of each grid by different substrates: A) Soil; B) Stones.

The regressions showed significant positive relationship between luminosity and temperature $\left(r^{2}=0.482 ; \mathrm{p}<0.01 ; \mathrm{F}=387.2\right)$ and significant negative relationship between temperature and moisture $\left(r^{2}=0.630 ; p<0.01 ; F=708.9\right)$ among climatic variables of temperature, humidity and light (Figs. 6 and 7).

\section{Faunistic groups}

We found 12,438 individuals distributed in 483 morphospecies of the following taxa: Araneae (96 spp), Acari (28 spp), Pseudoscorpiones (5 spp), Opiliones (4 spp), Palpigradi (1 sp), Isopoda (2 spp), Blattodea (9 spp), Coleoptera (97 spp), Collembola (20 spp), Dermaptera (1 sp), Diplura (4 spp), Diptera (49 spp), Ephemeroptera (1 sp), Hemiptera (29 spp), Hymenoptera (62 spp), Isoptera (2 spp), Lepidoptera (24 spp),

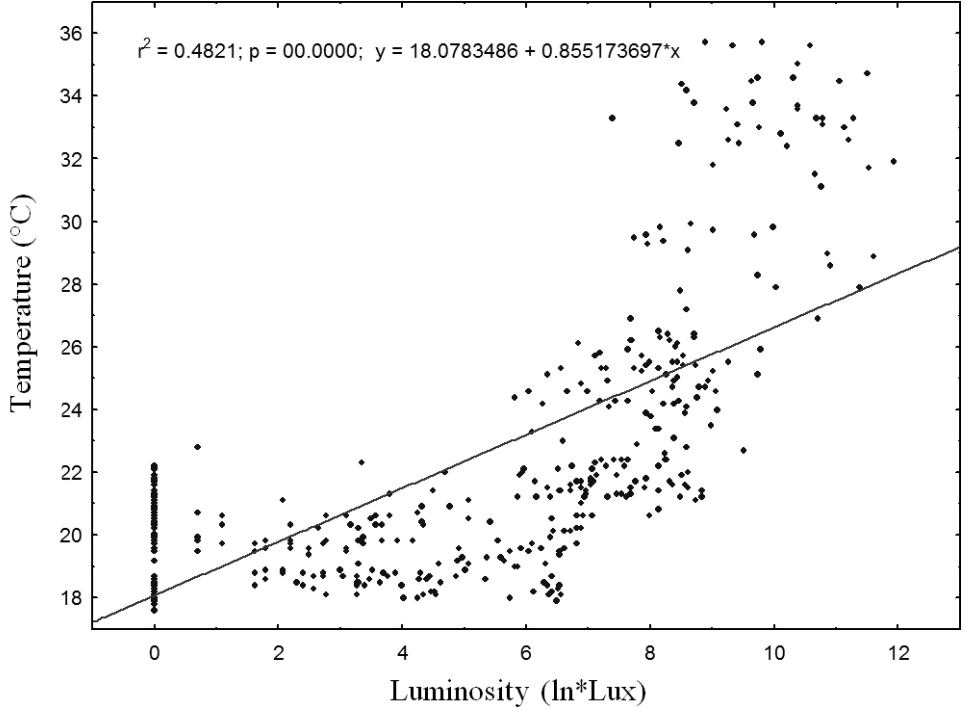

Fig. 6. Linear regression between temperature $\left({ }^{\circ} \mathrm{C}\right)$ and light (In*Lux). 


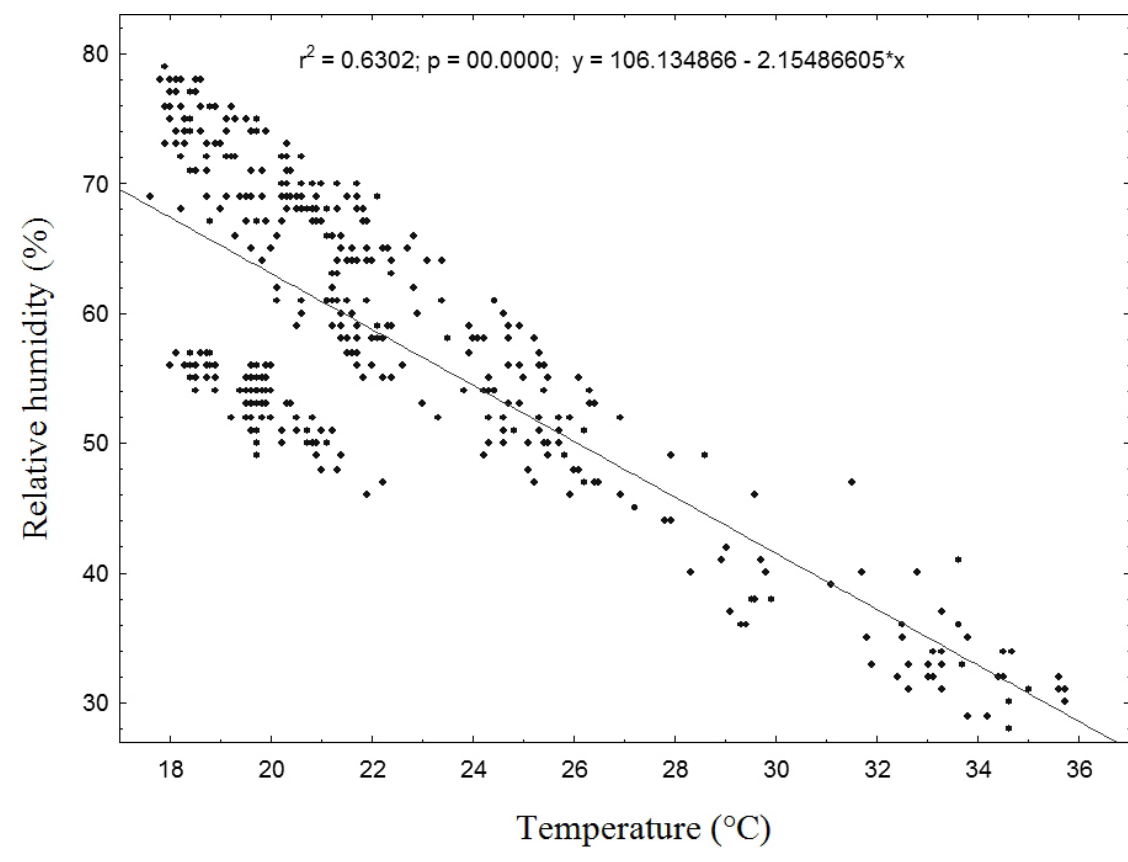

Fig. 7. Linear regression between relative humidity (\%) and temperature $\left({ }^{\circ} \mathrm{C}\right)$.

Most of the species were found in less than 40 sampled grid cells, and only 20 were present in at least $10 \%$ of the cells. These species belong to the orders Acari, Aranae (Sicariidae, Oecobidae, Pholcidae, Theridiidae), Opiliones, Pseudoscorpiones, Collembola (Entomobryiidae), Coleoptera, Diplura (Campodeidae), Hemiptera (Reduviidae), Hymenoptera (Formicidae), Lepidoptera (Tineidae), Psocoptera (Psyllipsocidae) and Polyxenida.

\section{Richness, diversity, and distribution patterns}

Similar patterns were observed for richness and diversity in the sectors (Figs. 8 and 9). Inside the cave both showed lower values compared to those found in the epigean sectors. However, in the region located at the entrance there is a gradual transition between the

Neuroptera (1 sp), Orthoptera (5 spp), Psocoptera (19 spp), Thysanoptera (2 spp), Diplopoda (8 spp), Chilopoda (7 spp), Symphyla (2 spp), Pauropoda (2 spp), Platyhelminthes (1 sp), Oligochaeta (1 sp) and Hirudinea (1 sp).

Many species (165 - 34.2\%) were only found in one cell. The vast majority of species $(77 \%, 372$ species) were found in to only one compartment (Epigean, Ecotone, Hypogean), with $63 \%$ of these present only in the epigean compartment (236 species), 15\% in the ecotone (55 species) and $22 \%$ in hypogean (82 species). Altogether, 14 species were present in all three compartments, 49 species were present in the epigean and ecotone compartments, 37 species in the hypogean and ecotone compartments and 11 species were present exclusively in the hypogean and epigean compartments (Table 2).

Table 2. Number of species found in different compartments of the Lapa do Mosquito (*altogether 11 species were found in common in hypogean and epigean compartments).

\begin{tabular}{cccc} 
Hypogean & Ecotone & Epigean \\
\hline & & 14 & \\
& & & 49 \\
& 37 & & \\
$11^{*}$ & & & $11^{*}$ \\
& & & 236 \\
\hline 82 & & 55 & \\
\hline
\end{tabular}

Among the arachnids, the Araneae order was the richest, with 96 species in at least 27 families. Theridiidae was the richest family (27 species), whereas the most abundant species were Loxosceles similis ( $\mathrm{n}=3,439)$ (Sicariidae) and Oecobius navus ( $\mathrm{n}=1,927)$ (Oecobidae).

Among the insects, Coleoptera was the richest, with 97 species in at least 18 families. The richest family was Staphylinidae, with 37 species, and the most abundant species was one of Tenebrionidae (95 individuals). epigean and hypogean environments. This transition comprises approximately $20 \mathrm{~m}, 10 \mathrm{~m}$ inside the cave and $10 \mathrm{~m}$ outside.

Homogeneity was observed in the richness values of inner sectors farthest from the cave entrance, which ranged between 4 and 8 species per sector. From the initial $10 \mathrm{~m}$ of the cave, there was a sharp increase in the number of species, with up to 19 species in the area located $8 \mathrm{~m}$ into epigean environment. Then a sharp drop in richness follows, which amounted to 11 species in the most external sector, $20 \mathrm{~m}$ from the cave entrance (Fig. 8).

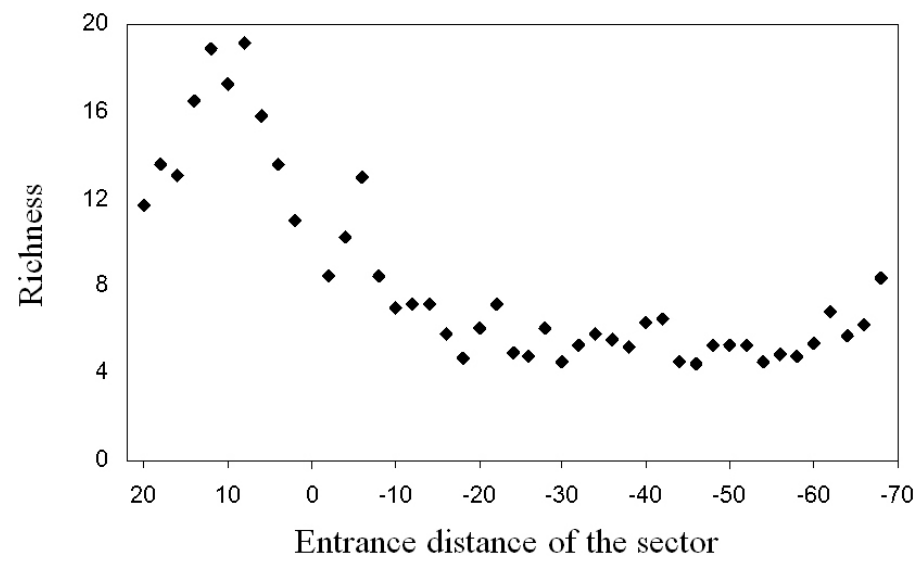

Fig. 8. Species richness values for each cell of each sector studied (negative values indicate the interior of the cave).

As with richness, diversity was low and relatively constant in the internal sectors farthest from the cave entrance, ranging between 0.6 and 1.0. However, in the entrance zone, from the first $6 \mathrm{~m}$ of the cave, there is a marked increase in diversity, reaching a level of 1.8 in the external sector located $6 \mathrm{~m}$ from the entrance. From this sector on, diversity remains around 1.8 until the last external sector, $20 \mathrm{~m}$ from the entrance (Fig. 9).

The regressions indicated significant and positive relationship $\left(\mathrm{F}=117.67 ; \mathrm{p}<0.01 ; \mathrm{r}^{2}=0.485\right)$ in the cells between richness and habitat diversity $(\beta=0.08)$, luminosity $(\beta=0.18)$ and temperature $(\beta=0.53)$. 


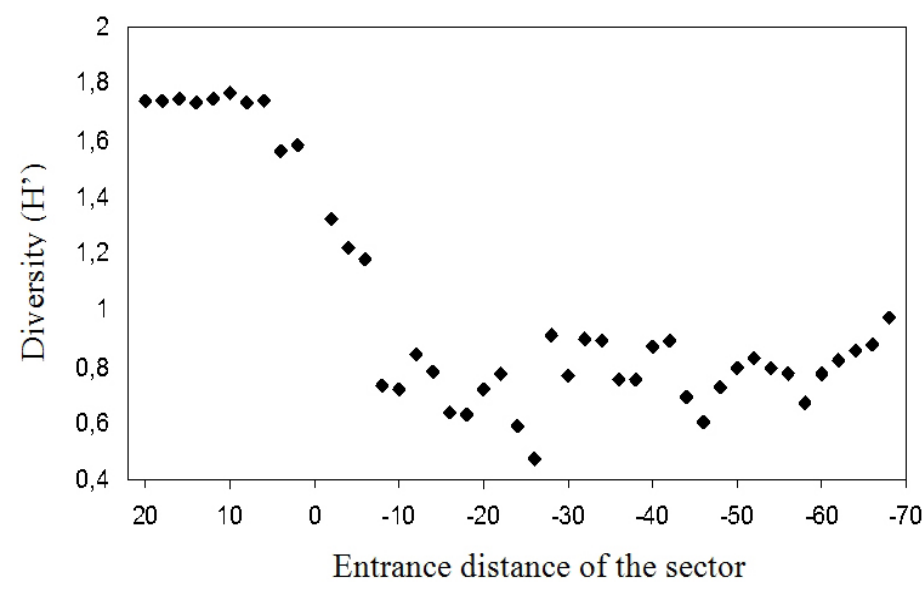

Fig. 9. Shannon diversity $\left(H^{\prime}\right)$ in the sectors studied (negative values indicate the interior of the cave).

\section{Delimitation of the ecotone community}

The values of similarity between the external reference sector and the other sectors and between the entrance reference sector and the other sectors of the cave are shown in Fig. 10. The similarity between the fauna of the external reference sector and other sectors decreased slowly towards the cave entrance. From the entrance of the cave there is a sharp decline in similarity values, reaching very low values from $10 \mathrm{~m}$ within the cave. The similarity values between the external reference sector and sectors located between 10 and $36 \mathrm{~m}$ inside the cave ranged from $0 \%$ to $2.75 \%$. When compared with the sectors located more than $36 \mathrm{~m}$ inside the cave, their similarity between the reference sector is zero.

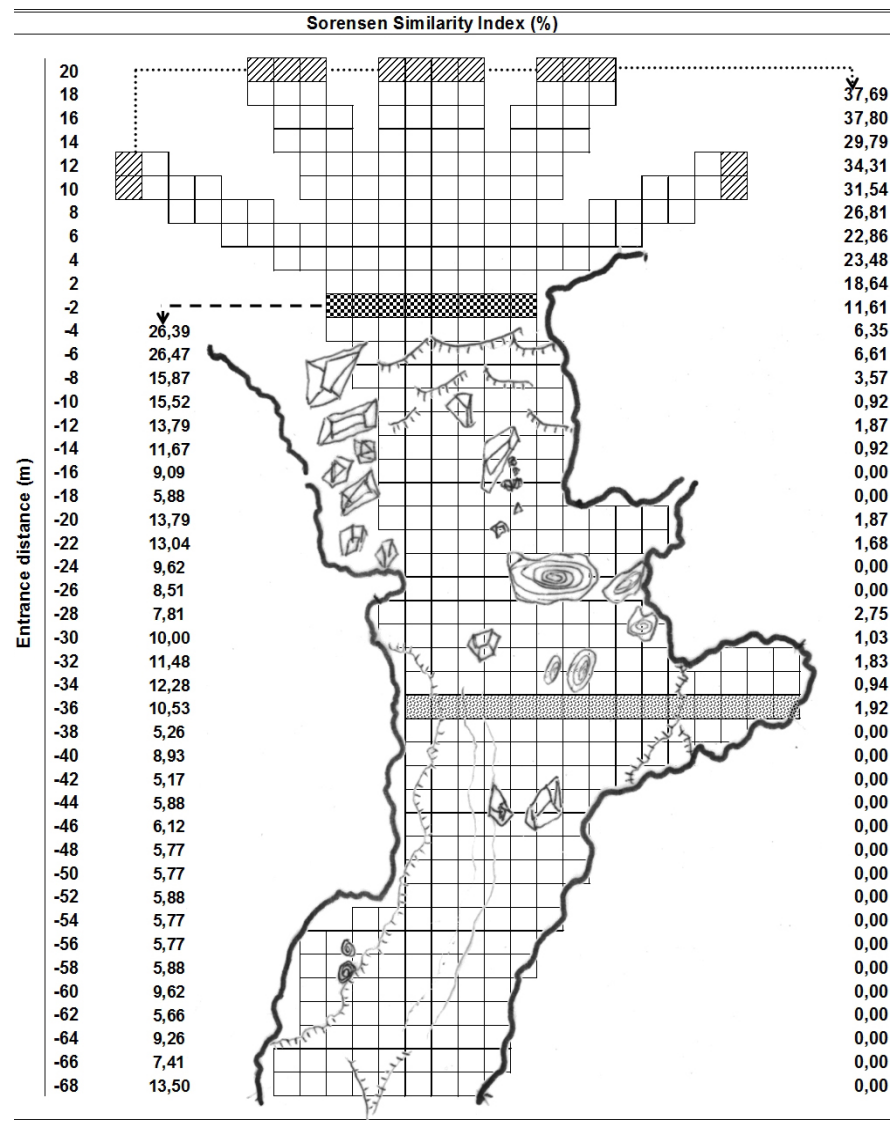

Fig. 10. Similarity (Sørensen index) between the external reference sector (diagonal lines) and other sectors, and between the internal reference sector (checkerboard) and other sectors of the cave. The dotted sector indicates the final sector of the ecotone community distribution.
Thus, from $38 \mathrm{~m}$ from the entrance of the cave there are no representative species present in the external reference sector.

The fauna in this reference entrance sector has similarity with all other cave sectors. Initially, the similarity decreases gradually from $26.39 \%$ compared with the sector at 4 meters from the entrance, up to $10.53 \%$ in the sector located $36 \mathrm{~m}$ from the cave entrance. The similarity between the first cave sector (entrance sector) and sectors located $38 \mathrm{~m}$ from the entrance shows a tendency towards stabilization of values, which fluctuated between $5.17 \%$ and $9.62 \%$. These latter values do not reach zero primarily for the presence of $L$. similis, Zelurus sp. and O. navus in almost all grid cells sampled.

Superimposing the external reference sector similarity values on the other values and the entrance reference sector similarity values on the others, there is a congruence in the position where the similarities hit their lowest values. From $38 \mathrm{~m}$ from the entrance an absence of epigean species, and the absence of species located at the entrance (except some species present throughout the cave environment) was observed.

When superposing both analysis, we can observe a more abrupt transition zone, corresponding to $20 \mathrm{~m}( \pm 10 \mathrm{~m}$ from the entrance). However, a more tenuous transition zone can also be observed, which extends until $38 \mathrm{~m}$ inside the cave.

\section{DISCUSSION}

Most of the works in cave environments are mainly foccused on troglobitic organisms and ecological generalizations are frequently made based on these species (Sket, 1999; Culver \& Sket, 2000; Christman \& Culver, 2001; Gibert \& Deharveng, 2002; Schneider \& Culver, 2004; Deharveng, 2005; Gibert \& Culver, 2005; Hobbs III, 2005; Humphreys, 2005). The frequent emphasis given to troglobite species may be important to discuss ecological patterns of organisms in this category, but may not be the best strategy when you want to evaluate the cave community as a whole, especially when dealing with tropical caves. This emphasis on troglobitic organisms demonstrates the low priority that many researches have been giving, historically, to the understanding of the functioning of cave environments as a whole (Ferreira, 2004; Lunghi et al., 2014). Although cave entrances are part of the cave system, little attention has been given to these regions and few studies have addressed the relationships of organisms present there to the subterranean environment (Culver \& Poulson, 1970; Peck, 1976; Gers, 1998; Prous et al., 2004; Novak et al., 2012; Lunghi et al., 2014; Manenti, 2014).

As suggested by Kark and van Rensburg (2006) "ecotones can be defined as areas of steep environmental transition along an environmental gradient, where the environment rapidly shifts from one type to another based on abiotic (e.g., climatic) and/or biotic factors". However, Kolasa \& Zalewsi (1995), demostrated that the evaluattion of ecotone atributes depends on the spatial and temporal scale in which the data is collected 
and the ecotone is conceptualized. Considering the ecotones between epigean and subterranean systems, there are also different approaches that have to be taken in account. Ecotones occur in all caves, and its dimension is extremelly variable. Some studies regarding groundwater/surface water ecotones have shown that these zones can extend for hundreds of kilometers (Gibert et al., 1990; Gibert et al., 1997). On the other side, Pellegrini \& Ferreira (2013) found an ecotone of few meters between a bat guano pile and the adjacente cave soil in a Neotropical cave in Brazil. Furthermore, there are also more generalistic (and realistic) approaches of the subterranean/external ecotones. Moseley (2009) purposed that caves are environmental and faunistic transitional regions between the surface and the host rock fissure system, thus, can be entirely considered as ecotones.

In this study, we used different biotic and abiotic parameters in order to identify the ecotone extension in the cave entrance. Considering the biotic parameters (richness and diversity), we could identify an "abrupt" transition, extending from the dripline until $10 \mathrm{~m}$ inside the cave. However, when considering the abiotic parameters, especially luminosity, it is possible to identify a wider transition zone, which extends until $38 \mathrm{~m}$ inside the cave. Accordingly, the ecotone zone is actually "fractionated", being composed by two areas: the abrupt ecotone (10 $\mathrm{m}$ inward the cave) and the "tenuous" ecotone, which could be considered as an "amortization" of the main, biological and abrupt, ecotone (38 $\mathrm{m}$ inward the cave).

Thus, as porposed by Kolasa \& Zalewsi (1995) we could identify two different ecotone "ranges". The first comprising a wider zone, more determined by physical atributes that could vary more rapidly depending on seazonal external changes (e.g., temperature, moisture and luminosity). The second consists in a narrower and abrupt transition zone, determined by biological attributes, which probably show slower responses to environmental changes.

Both ecotones zones are extremely important, apart from being certainly interdependent. Furthermore, both zones are centainly dynamic, and their extension can increase or descrease depending on the seazon. Unfortunately, we only performed one collection, what prevent us to explore such dynamic nature of the ecotone zone.

\section{The physical environment of the entrance}

The entrance of Lapa do Mosquito is an obvious climatic transition zone between the epigean and hypogean environments where, towards the interior, the temperature and humidity ranges are lessened, an effect already observed in other studies (Turquin \& Bouvet, 1977; di Russo et al., 1997; Serena \& Meluzzi, 1997; Pentecost \& Zhaohui, 2001).

At the entrance of the Lapa do Mosquito, the regressions showed a clear relationship between luminosity and temperature, but only up to a certain light intensity ( 5 ln Lux). At lower intensities, the temperature is stabilized regardless of the luminosity, that continues to fall, similar to that found by Pentecost and Zhaohui (2001). This precludes the adoption of climatically distinct "zones" that include areas of penumbra, variable temperature and constant temperature (Mohr \& Poulson, 1966; Poulson \& White, 1969). As noted by Gamble et al. (2000), it is evident that this zoning, initally suggested for caves in temperate environments, can hardly be adopted for tropical caves, since the latter are subject to wider temperature and moisture ranges than those present in temperate region caves, so that these zones may vary over the course of one day.

Since the presence of light at the entrances of caves is a major factor for the presence of several organisms (Serena \& Meluzzi, 1997; Pentecost \& Zhaohui, 2001), the definition of zones based on that variable can be more appropriate from a biological point of view. Culver (1982) described a zonation composed of the euphotic zone (where there is incidence of direct light), disphotic (where there is incidence of reflected light) and aphotic. Lightness values below 5 ln Lux (from which there is temperature stabilization) occur at about $30 \mathrm{~m}$ from the entrance of Lapa do Mosquito Cave and correspond to the beginning of the disphotic region, reinforcing the consistency of this zonation. Thus, the use of this zonation seems to be more consistent in the cave studied and possibly for other caves located in tropical regions.

\section{Spatial patterns of richness and diversity}

The overall diversity of cave communities is notoriously low compared to that observed in epigean environments. Sket (1999) posed three reasons to explain this low diversity: 1 - Limited access to the habitat - the entrances are few and small compared to the total area of the cave, restricting the ability of a particular organism find this entry and access it; 2 - Relative habitat homogeneity - the habitat diversity is very low compared to epigean environments with vegetation and climate variations; 3 - Low energy availability the absence of primary producers, with the exception of some chemoautotrophs, restricts the availability of food resources. The low diversity and richness found in the deepest hypogean part of the study area compared to the epigean environment may reflect the relative homogeneity of the habitat in areas farther from the entrance and the low availability of food resources. The wind is not very efficient as a vehicle regarding the transport of large particles for large distances, and most of the organic matter is located in the first few meters of the cave, where there is a large slope. In regions farther from the entrance, the floor was covered almost entirely by earth. Furthermore, temperature, humidity and light were environmental attributes only slightly variable. These factors result in a lower habitat and trophic resource diversity and therefore less biological diversity. Other studies have shown that the structural complexity of the habitat within caves has a positive relationship with important arthropod diversity (Culver, 1969; Poulson \& Culver, 1969).

Since cave entrances are considered ecotones and that one of the typical characteristics of ecotones is the presence of species from adjacent environments plus the exclusive species, it would be natural to admit that this area is the most diverse or richest in species. 
The entrance of the Lapa do Mosquito, however, presented an intermediate diversity and richness to those of adjacent epigean and hypogean environments. These results confirm the predictions of Hansen et al. (1988a), who argue that intermediate diversity can be found in ecotones present between environments of very distinct diversity, in which one environment has much higher diversity values than those found in the surrounding environment. Furthermore, several other authors, also working on ecotones, also found intermediate values of richness and diversity in comparison to the adjacente systems (Heliola et al. 2001; Malan, 2001; Dangerfield et al., 2003; Spector \& Ayzama, 2003). In ecotones located at the entrances of caves Culver \& Poulson (1970), Gers (1998) and Prous et al. (2004) also noted that diversity and richness are intermediate to those found in epigean and hypogean environment.

Hansen et al. (1988a) have also suggested that a lower diversity can be found in ecotones comprising areas susceptible to severe and constant disorders. Peck (1976) observed a lower biodiversity at the entrance of a cave located in a temperate region (Alabama, United States), which undergoes strong annual temperature ranges. To date, there are no studies that have established that the diversity is greater at the entrance of the caves.

\section{Cave entrances as ecotone with selective membrane function}

Ecotones are described as membranes of selective permeability to their biotic and abiotic components (Bider, 1968; Wegner \& Merriam, 1979; Wiens et al., 1985; Schonewald-Cox \& Bayless, 1986; Hansen et al., 1988a; Hansen et al., 1988b; Johnston \& Naiman, 1987; Fagan et al., 1999; Prous et al., 2004; Yarrowa $\&$ Salthe, 2008). The drop in the number of herbivores in the transition from the epigean to hypogean, and the reduction in the richness generally indicates the cave entrance functions as a membrane of selective permeability, as suggested by Prous et al. (2004).

According to Strayer et al. (2003) this "membrane" can act on species, matter or energy in different ways, and can partially transmit them, transform them, absorb them, reflect them, amplify them or act neutrally. The filters present in these membranes can be biological or physical. Most species of the Lapa do Mosquito epigean and hypogean environment are not able to cross this membrane located at the entrance. The entrance of the cave acts as an impermeable membrane for these species, not allowing the passage of organisms from one environment to the other, since this entrance is dry compared with the adjacent environments. This impermeability effect of the transition areas on animals is well documented (Wiens et al., 1985; Duelli et al., 1990; Fagan et al., 1999; Lidicker, 1999).

Several predator species (e.g. Salticidae) and herbivores (e.g., Cicadelidae) are absorbed by the ecotone, being able to establish themselves in the entrance area where there is still enough light to allow visual predation and the presence of photosynthesiziers, but unable to colonize the environment within the caves. In this case, the ecotone can function as a "sink", where some species are able to colonize the area, although the ecotone itself do not represent their optimum habitat. Therefore, some of these species may reach the edges of their distribution range at the ecotone (comprising peripheral populations) (Shmida \& Wilson, 1985). According to Sket (2008) accidental species "are not very important for understanding subterranean life or for the refinement of theoretical speleobiological questions". However, such species can have special importance in some cave food webs, as in the case of some ecotonal communities.

Some species of generalist predators, very common in the hypogean environment, like spiders of the genus Loxosceles and Isoctenus and hemipterans of the genus Zelurus, had their populations increased when they colonized the caves. The strong selective pressures of the cave environment, such as low abundance of potential prey and the absence of light, restrict the colonization and establishment of populations within the cave to a few generalist predators pre-adapted to the hypogean conditions. The reduction in interspecific competition and intra-guild predation caused by the reduction of predators enables the increase in the population size of species able to colonize the hypogean environment when compared with epigean environment populations.

The light seems to be one of the most important filters of this membrane, preventing the presence, inside the cave, of any organisms (predators, herbivores and detritivores) that depend on it to hunt or find their food. However, apparently the presence of light is not the only filter, since the distribution of the species present in the ecotone is not directly associated to it, there being no reduction of all species as the light itself decreases. This fact indicates the presence of other filters influencing the presence or distribution of species in the ecotone zone.

The environmental stability and food availability can also function as filters. The presence of larvae of Neuroptera (Myrmeleontidae - antlion) in a given area is strongly associated with the presence of prey and environmental factors such as temperature and soil compaction and the frequency of trap disturbance (falling leaves, rain) (Gotelli, 1993; Gatti \& Farji-Brener, 2002; Farji-Brener, 2003). The antlion has the great benefit of taking shelter in the cave entrance, reducing the risk of their traps being destroying by rain or leaf fall and being under shelter from intense insolation. Allied to this environmental stability is the high frequency of potential prey, such as ants and beetles, present in large numbers in the epigean environment and that transit through there. Despite the abundance of prey not being considered a determining factor in the distribution of antlion populations (Gotelli, 1993; Crowley \& Linton, 1999), it is likely that colonization of the hypogean environment by these species is hindered by shortage in abundance of cursorial prey, which is a filter that influences the antlion distribution. In the two registrations of antlion larvae inside Brazilian caves (in aphotic), they were on guano patches and did not built funnel traps (Ferreira 
\& Martins, 1999). However, the predation behavior was not visualized.

Interactions among species also include biological filters. The high abundance of spiders of the genus Loxosceles and antlion on the floor of the tropical cave entrances can act as a filter absorbing cursorial epigean species that "venture out" to enter the caves. Likewise, these predators can prevent the exit of individuals who could at some point colonize the interior of the cave. One piece of evidence that predators can act as a filter at the entrances of the caves is the fact that most trogloxene organisms (harvestmen, bats, moths, crickets) are winged or parietal (moving on cave walls) avoiding predation by predators on the soil, like antlions and spiders Loxosceles spp.

Moreover, in tropical caves, most invertebrate species are troglophilic, even species of large size and high motility. Thus, even being able to move into epigean systems (notoriously rich in food), most species seems to prefer to stay inside the caves, avoiding regular movements between epigean and hypogean systems. Such behavior may possibly be due to the presence of these important biological filters (predators) established at the entrances of caves, which act continuously selecting species apt to remain inside the caves.

Thus, the ecotones at cave entrances serve as selective permeability membranes, acting in different ways on different species. The combination of the different biotic and abiotic filters is responsible for the presence and distribution of species at the entrances of the caves as well as within them.

Since the spatial arrangement of the ecotone community depends on the combination of various factors, including climate, it is important to note that seasonal variations can lead to changes in the community over time. Probably ecotone communities are dynamic, modifying their spatial structure in response to external variations (Prous et al., 2004).

\section{Final considerations}

Human actions have generated major changes in cave ecosystems, such as cave suppression, alterations in water dynamics, eutrophication of waterways, changes in food supply, among others (Gibert, 1997; Horta \& Ferreira, 2001; Elliott, 2005). Cave entrances are regions that often undergo changes and impacts of anthropogenic nature, such as deforestation, corral setups, residential construction, material deposits, dams, shrines, tourist infrastructure and even scientific research (e.g., paleontological and archaeological excavations). The impacts caused by various human activities range from the ad hoc, such as trampling from a sporadic visitation to large-scale impacts such as floods and excavations, which can lead to the complete destructuring of cave entrances and consequently the communities associated with them.

Various studies have demonstrated how cave systems depend on epigean environments to maintain their structure, mainly as suppliers of food (Clarke, 1997; Gillieson \& Thurgate, 1999; Simon \& Benfield, 2001; Poulson, 2005; Souza-Silva et al., 2012).
Despite the importance of cave entrances as interfaces between epigean and hypogean environments, influencing the flow of nutrients and the ecotone and cave community structure a whole, studies on how changes in the epigean environment can affect entrance areas and their communities are still very scarce, most are restricted to aquatic environments (Gibert et al., 1990; Gibert \& Fournier, 1997; Gillieson $\&$ Thurgate, 1999; Neil, 2004; Sharipova \& Abdullin, 2007). This neglect of the cave entrances is due to various reasons such as:

1) incorrect application of presumption, assuming, for example, that this is a region that can contribute little to the cave community, or, assuming that being an ecotone zone, it has greater diversity;

2) difficulty of working in such environments, since they are no longer stable and simplified environments as is the hypogean, considered an ideal laboratory for ecological studies (Culver, 1982);

3) greater historical interest for troglobite species, which tend to preferentially distribute in regions farther from the entrances;

4) greater interest in population studies than in studies on the ecosystem as a whole.

The caves should be considered as a functional unit, consisting of different species, with varying degrees of specialization and ecological processes that depend on intrinsic ecological processes and others directly connected to the external environment (Poulson, 2005; Moseley, 2009). From this perspective, studies of cave entrances and their respective communities are paramount for any action toward their conservation and management.

\section{ACKNOWLEDGMENTS}

We would like to thank Dr. David Culver and Dr. Max Moseley for their suggestions that certainly improved the manuscript. Thanks to all the colleagues who assisted in the field and laboratory work, particularly to Marconi, Érika, Felipe, Edelvânia, Deise, Vanessa, Randérley, Diogo. Special thanks to Ricardo for the indication of the cave to implement the survey. All organisms were collected in accordance with the license provided by IBAMA/CECAV ( $\mathrm{n}^{\circ}$ 02015.02006.21200355) for this research. RLF is also grateful to the Conselho Nacional de Desenvolvimento Cientifico $e$ Tecnológico (CNPq grant nr. 301061/2011-4).

\section{REFERENCES}

Bider J.R., 1968 - Animal activity in uncontrolled terrestrial communities as determined by a sand transect technique. Ecological Monographs, 38 (4): 269-308. http://dx.doi.org/10.2307/1948530

Cadenasso M.1., Pickett S.T.A., Weathers K.C., Bell S.S., Benning T.I., Carreiro M.M. \& Dawson T.E., 2003 - An Interdisciplinary and synthetic approach to ecological boundaries. BioScience, 53 (8): 717-728.

http://dx.doi.org/10.1641/0006-3568(2003)053 [0717:AIASAT]2.0.CO;2 
Christman M.C. \& Culver D.C., 2001 - The relationship between cave biodiversity and available habitat. Journal of Biogeography, 28 (3): 367-380. http://dx.doi.org/10.1046/j.1365-2699.2001.00549.x

Clarke A., 1997 - Impacts on invertebrate cave fauna in forested karst ecosystems and recommended protection measures in forested karst areas of Tasmania. In: Stitt R.R. (Ed.), Proceedings of the 1997 Karst and Cave Management Symposium: 44-52.

Crowley P. \& Linton M., 1999 - Antlion foraging tracking prey across space and time. Ecology, 80 (7): 2271-2282. http://dx.doi.org/10.1890/0012-9658(1999)080 [2271:AFTPAS]2.0.CO;2

Culver D.C., 1982 - Cave life. Evolution and ecology. Harvard University Press, Cambridge, 189 p. http://dx.doi.org/10.4159/harvard.9780674330214

Culver D.C. \& Pipan T., 2009 - The biology of caves and other subterranean habitats. Oxford University Press, Oxford, 256 p.

Culver D.C. \& Poulson T.L., 1970 - Community boundaries: Faunal diversity around a cave entrance. Annales Spéléologie, 25 (4): 853-860.

Culver, D.C. \& Sket, B., 2000 - Hotspots of subterranean biodiversity in caves and wells. Journal of Cave and Karst Studies, 62: 11-17.

Culver D.C., 1969 - Analysis of simple cave communities I. Caves as islands. Evolution, 24 (2): 463-474. http://dx.doi.org/10.2307/2406819

Culver D.C., 2005 - Ecotones. In: Culver D.C. \& White W.B. (Eds.), Encyclopedia of caves. Amsterdam: Elsevier Academic Press: 206-208.

Dangerfield J.M., Pik A.J., Britton D., Holmes A., Gillings M., Oliver I., Briscoe D. \& Beattie, A.J., 2003 - Patterns of invertebrate biodiversity across a natural edge. Austral Ecology, 28 (3) : 227-236.

http://dx.doi.org/10.1046/j.1442-9993.2003.01240.x

Deharveng L., 2005 - Diversity patterns in the tropics. In: Culver D.C. \& White W.B. (Eds.), Encyclopedia of caves. Amsterdam: Elsevier Academic Press: 166-170.

di Russo C., Carchini G., Rampini M., Lucarelli M. \& Shordoni V., 1997 - Long term stability of a terrestrial cave community. International Journal for Speleology, 26 (1-2): 75-88.

http://dx.doi.org/10.5038/1827-806X.26.1.7

Duelli P., Studer M., Marchand I. \& Jakob S., 1990 Population moovement of arthropods between natural and cultivate areas. Biological Conservation, 54 (3): 193-207. http:/ /dx.doi.org/10.1016/0006-3207(90)90051-P

Elliot W.R., 2005 - Protecting caves and cave life. In: Culver D.C. \& White W.B. (Eds.), Encyclopedia of caves. Amsterdam: Elsevier Academic Press: 458-467.

Engel A.S., 2005 - Chemoautotrophy. In: Culver D.C. \& White W.B. (Eds.), Encyclopedia of caves. Amsterdam: Elsevier Academic Press: 90-102.

Fagan W.F., Fortin M.J. \& Soykan C., 2003 - Integrating edge detection and dynamic modeling in quantitative analyses of ecological boundaries. BioScience, 53 (8): 730-738. http://dx.doi.org/10.1641/0006-3568(2003)053 [0730:IEDADM]2.0.CO;2

Fagan W.F., Cantrell R.S. \& Cosner C., 1999 - How habitat edges change species interactions. The American Naturalist, 153 (2): 165-182.

http://dx.doi.org/10.1086/303162

Farji-Brener A.G., 2003 - Microhabitat selection by antlion larvae, Myrmeleon Crudelis: Effect of soil particle size on pit-trap design and prey capture. Journal of Insect Behavior, 16 (6): 783-796.

http://dx.doi.org/10.1023/ B:JOIR.0000018320.99463.ee
Ferreira R.L. \& Martins R.P., 1999 - Trophic structure and natural history of bat guano invertebrate communities, with special reference to Brazilian caves. Tropical Zoology, 12 (2): 231-52.

http://dx.doi.org/10.1080/03946975.1999.10539391

Ferreira R.L. \& Martins R.P., 2001 - Cavernas em risco de 'extinção'. Ciência Hoje, 29: 20-28.

Ferreira R.L. \& Martins R.P., 1998 - Diversity and distribution of spiders associated with bat guano piles in Morrinho cave (Bahia State, Brazil). Diversity and Distributions, 4: 235-241.

Ferreira R.L., 2004 - A medida da complexidade ecológica e suas aplicações na conservação e manejo de ecossistemas subterrêneos. PhD Thesis. Universidade Federal de Minas Gerais, Brasil, 161 p.

Ferreira R.L. \& Horta L.C.S., 2001 - Natural and human impacts on invertebrate communities in Brazilian caves. Revista Brasileira de Biologia, 61 (1): 7-17. http://dx.doi.org/10.1590/S0034-71082001000100003

Gamble D.W., Dogwiler J.T. \& Mylroie J., 2000 - Field assessment of the microclimatology of tropical flank margin caves. Climate Research, 16: 37-50.

http://dx.doi.org/10.3354/cr016037

Gatti G. \& Farji-Brener A.G., 2002 - Low density of antlion larvae (Myrmeleon crudelis) in ant-acacia clearings: High predation risk or inadequate substrate? Biotropica, 34 (3): 358-362.

http://dx.doi.org/10.1111/j.1744-7429.2002.tb00561.x

Gers C., 1998 - Diversity of energy fluxes and interactions between arthropod communities: from soil to cave. Acta Oecologica, 19 (3): 205-213.

http:/ /dx.doi.org/10.1016/S1 146-609X(98)80025-8

Gibert J. \& Deharveng L., 2002 - Subterranean ecosystems: A truncated functional biodiversity. BioScience, 52 (6): 473-481.

http://dx.doi.org/10.1641/0006-3568(2002)052 [0473:SEATFB]2.0.CO;2

Gibert J., 1997 - The importance of ecotones in karstlands. In: Sasowsky I.D., Fong D.W. \& White E.L. (Eds.), Conservation and Protection of the Biota of Karst. Karst Water Institute, University of Akron: 17-19.

Gibert J. \& Culver D.C., 2005 - Diversity patterns in Europe. In: Culver D.C. \& White W.B. (Eds.), Encyclopedia of caves. Amsterdam: Elsevier Academic Press: 196-201.

Gibert J., Dole-Olivier M.J., Marmonier P. \& Vervier P.H., 1990 - Surface water-groundwater ecotones. In: Naiman R.J. \& Decamps H. (Eds.), The Ecology and Management of Aquatic-Terrestrial Ecotones: Parthenon Publications, Carnforth: 199-204.

Gibert J., Mathieu J. \& Fournier F., 1997 - Groundwater/ Surface water ecotones: Biological and hydrological interactions and management options. International Hydrobiology Series. Cambridge University Press, Cambridge, $246 \mathrm{p}$.

http://dx.doi.org/10.1017/CBO9780511753381

Gillieson D. \& Thurgate M., 1999 - Karst and agriculture in Australia. International Journal of Speleology, 28B (1/4): 149-168.

Gotelli N.J., 1993 - Ant lion zones: causes of high-density predator aggregations. Ecology, 74 (1): 226-237.

http://dx.doi.org/10.2307/1939517

Hansen A.J., di Castri F. \& Naiman R.J., 1988a Ecotones: what and why? Biology International Special Issue, 17: 9-46.

Hansen A.J., di Castri F. \& Risser P.G., 1988b - A new SCOPE project. Ecotones in a changing environment: The theory and management of landscape boundaries. Biology International Special Issue, 17: 137-63. 
Heliola J., Koivula M. \& Niemela J., 2001 - Distribution of carabid beetles (Coleoptera, Carabidae) across a boreal forest-clearcut ecotone. Conservation Biology, 15 (2): 370-377. http://dx.doi.org/10.1046/j.15231739.2001.015002370.x

Hills N., Hose G.C., Cantlay A.J. \& Murray B.R., 2008 - Cave invertebrate assemblages differ between native and exotic leaf litter. Austral Ecology, 33 (3): 271-277. http://dx.doi.org/10.1111/j.1442-9993.2007.01814.x

Hobbs III H.H., 2005 - Diversity patterns in the United States. In: Culver D.C. \& White W.B. (Eds.), Encyclopedia of caves. Amsterdam: Elsevier Academic Press: 170-183.

Howarth F.G., 1983 - Ecology of cave arthropods. Annual Rewiew os Entomology, 28: 365-389.

Humpheys W.F., 2005 - Diversity patterns in Australia. In: Culver D.C. \& White W.B. (Eds.), Encyclopedia of caves. Amsterdam: Elsevier Academic Press: 183-196.

Johnston C.A. \& Naiman R.J., 1987 - Boundary dynamics at the aquatic-terrestrial interface: The influence of beaver and geomorphology. Landscape Ecology, 1:47-57. http://dx.doi.org/10.1007/BF02275265

Kark S. \& van Rensburg B.J., 2006 - Ecotones: Marginal or central areas of transition? Israel Journal of Ecology and Evolution, 52 (1): 29-53.

http://dx.doi.org/10.1560/IJEE.52.1.29

Kolasa J. \& Zalewski M., 1995 - Notes on ecotone attributes and function. Hydrobiologia, 303: 1-7. http://dx.doi.org/10.1007/BF00034039

Lidicker W.Z., 1999 - Responses of mammals to habitat edges: An overwiew. Landscape Ecology, 14: 333-343. http://dx.doi.org/10.1023/A:1008056817939

Lunghi E., Manenti R. \& Ficetola G.F., 2014 - Do cave features affect underground habitat exploitation by nontroglobite species? Acta Oecologica, 55: 29-35. http://dx.doi.org/10.1016/j.actao.2013.11.003

Magurran A.E., 1988. Ecological diversity and its measurement. New Jersey: Princeton, University Press, 179 p. http://dx.doi.org/10.1007/978-94-015-7358-0

Malan G., 2001 - The avifauna of riparian-Pinus habitat edges at Mooiplaas forestry estate, Kwa-Zulu-Natal, South Africa. South African Journal of Wildlife Research, 31: 73-84.

Manenti R., 2014 - Role of cave features for aquatic troglobiont fauna occurrence: Effects on "accidentals" and troglomorphic organisms distribution. Acta Zoologica Academiae Scientiarum Hungaricae, 60 (3): 257-270.

Mohr C.E. \& Poulson T.L., 1966 - The life of the cave: Our living world of nature. McGraw Hill, 232 p.

Moseley M., 2009 - Are all caves ecotones. Cave and Karst Science, 36 (2): 53-58.

Neill H., Gutierrez M. \& Aley T., 2004 - Influences of agricultural practices on water quality of Tumbling Creek cave stream in Taney County, Missouri. Environmental Geology, 45: 550-559.

http://dx.doi.org/10.1007/s00254-003-0910-2

Novak T., Perc M., Lipovsek S. \& Janžekovič F., 2012 Duality of terrestrial subterranean fauna. International Journal of Speleology, 41 (2): 181-188.

http://dx.doi.org/10.5038/1827-806X.41.2.5

Peck S.B., 1976 - The effect of cave entrances on the distribution of cave-inhabiting terrestrial arthropods. International Journal of Speleology, 8 (4): 309-321. http://dx.doi.org/10.5038/1827-806X.8.4.1

Pentecost A. \& Zhaohui Z., 2001 - The distribution of plants in Scoska cave, North Yorkshire, and their relationship to light intensity. International Journal of Speleology, 30A (1/4): 27-37.

http://dx.doi.org/10.5038/1827-806X.30.1.3
Poulson T.L., 2005 - Food sources. In: Culver D.C. \& White W.B. (Eds.), Encyclopedia of caves. Amsterdam: Elsevier Academic Press: 255-264.

Poulson T.L. \& Culver D.C., 1969 - Diversity in terrestrial cave communities. Ecology, 50 (1): 153-158.

http://dx.doi.org/10.2307/1934678

Poulson T.L. \& White W.B., 1969 - The cave environment. Science, 165: 971-981.

http://dx.doi.org/10.1126/science.165.3897.971

Prous X., Ferreira R.L. \& Martins R.P., 2004 - Ecotone delimitation: Epigean-hypogean transition in cave ecosystems. Austral Ecology, 29 (4): 374-382.

http://dx.doi.org/10.1111/j.1442-9993.2004.01373.x

Ries L., Fletcher Jr. R.J., Battin J. \& Sisk T.D., 2004 - Ecological responses to habitat edges: mechanisms, models and variability explained. Annual Review in Ecology, Evolution and Systematics, 35: 491-522.

http://dx.doi.org/10.1146/annurev. ecolsys.35.112202.130148

Risser P.G., 1990 - The ecological importance of land/ land-water ecotones. In: Naiman R.J. \& Decamps $\mathrm{H}$. (Eds.), The ecology and management of aquaticterrestrial ecotones. United Nations Educational, Scientific and Cultural Organization (UNESCO). Carnforth: Parthenon Press Publications: 7-21.

Risser P.G., 1995 - The status of the science examining ecotones. Bioscience, 45 (5): 318-325.

http://dx.doi.org/10.2307/1312492

Sarbu S.M., Kane T.C. \& Kinkle B.K., 1996 - A chemoautotrophically based cave ecosystem. Science, 272: 1953-1955.

http://dx.doi.org/10.1126/science.272.5270.1953

Schneider K. \& Culver D.C., 2004 - Estimating subterranean species richness using intensive sampling and rarefaction curves in a high density cave region in west Virginia. Journal of Cave and Karst Studies, 66 (2): 39-45.

Schonewald-Cox C. \& Bayless J.W., 1986 - The boundary model: a geographical analysis of design and conservation of nature reserves. Biological Conservation, 38 (4): 305-322.

http://dx.doi.org/10.1016/0006-3207(86)90057-1

Serena F. \& Meluzzi C., 1997 - Species assemblages and light trend in the zoning of Tana di Casteltendine (Lucca-Italy) entrance. Mémoires de Biospéologie, 24: $183-190$.

Shmida A. \& Wilson M.V., 1985 - Biological determinants of species diversity. Journal of Biogeography, 12 (1): 1-20. http://dx.doi.org/10.2307/2845026

Sharipova M.Y. \& Abdullin S.R. 2007 - Algological investigation of cave ecotones. Siberian Journal of Ecology, 14 (6): 1017-1023.

Simon K.S. \& Benfield E.F., 2001. Leaf and wood breakdown in cave streams. Journal of the North American Benthological Society, 20:550-563. http://dx.doi.org/10.2307/1468087

Sket B., 1999 - The nature of biodiversity in hypogean waters and how it is endangered. Biodiversity and Conservation, 8 (10): 1319-1338.

http://dx.doi.org/10.1023/A:1008916601121

Souza-Silva M, Bernardi L.F.O., Martins R.P. \& Ferreira R.L., 2012 - Transport and consumption of organic detritus in a neotropical limestone cave. Acta Carsologica, 41 (1): 139-150.

Spector S. \& Ayzama S., 2003 - Rapid turnover and edge effects in dung beetle assemblages (Scarabaeidae) at a Bolivian neotropical forest-Savanna ecotone. Biotropica, 35: 394-404. 
Strayer D.L., Power M.E., Fagan W.F., Pickett S.T.A. \& Belnap J., 2003 - A classification of ecological boundaries. BioScience, 53 (8): 723-729. http://dx.doi.org/ 10.1641/0006-3568(2003)053[0723:ACOEB]2.0.CO;2

Turquin M.J. \& Bouvet Y., 1977 - Vertical zonation of soil organisms in a karstic area (French Jura). Ecological Bulletin, 25: 506-508.

Wegner J. F., \& Merriam G., 1979 - Movements by birds and small mammals between a wood and adjoining farmland habitats. Journal of Applied Ecology, 8: 349-357. http://dx.doi.org/10.2307/2402513
Wiens J.A., Crawford C.S. \& Gosz J.R., 1985 - Boundary dynamics: a conceptual framework for studying landscape ecosystems. Oikos, 45 (3): 412-427. http://dx.doi.org/10.2307/3565577

Yarrowa M.M. \& Salthe S.N., 2008 - Ecological boundaries in the context of hierarchy theory. BioSystems, 92 (3): 233-244.

http://dx.doi.org/10.1016/j.biosystems.2008.03.001

Zar J.H., 1996 - Bioestatistical analysis (3 ${ }^{\text {rd }}$ Ed.). New Jersey, Prentice Hall, 662 p. 